\title{
DEBT IPO WAVES, INVESTOR SENTIMENT, MARKET CONDITIONS, AND ISSUE QUALITY
}

\author{
Kelly Nianyun Cai \\ University of Michigan, Dearborn \\ Xiaoquan Jiang \\ Florida International University \\ Hei Wai Lee \\ University of Michigan, Dearborn
}

\begin{abstract}
We examine the aggregate volume of straight debt initial public offerings (DIPOs) from 1970 to 2010 . We find that aggregate DIPO activities display wave patterns. Both the number and total proceeds of DIPOs vary substantially over time. DIPO volume is significantly associated with yield spread, aggregate book-to-market ratio, stock return volatility, lagged equity IPO volume, and term spread, suggesting that investor sentiment and capital market conditions play significant roles in explaining time variations in DIPO volume. We also find that speculative-grade DIPO issues synchronize with the business cycles, while investment-grade issues display a steady or countercyclical pattern.
\end{abstract}

JEL Classification: G10, G12

\section{Introduction}

A debt initial public offering (DIPO) (i.e., the issuing firm accessing the public debt market for the first time) represents a major shift in a firm's financing policy. A DIPO offers the issuing firm added liquidity, flexibility, and borrowing capacity. But at the same time, it brings to the issuing firm costs of public debt such as third-party monitoring from bond analysts and rating agencies (Hale and Santos 2008) and the possible holdup by underwriters. In addition, public debt typically extends the issuer's average debt maturity, a negative signal of the issuer's financial performance (Datta, Datta, and Patel 2000). Despite the transforming impact of DIPOs on the financial flexibility of issuing firms, the amount of research on DIPOs is scarce and limited to the price reactions in capital markets. For instance, Datta, Datta, and Patel (1997) find that IPOs of speculative-grade bonds are underpriced while those of investment-grade bonds are overpriced. Cai, Helwege, and Warga (2007) find that underpricing occurs with both DIPOs and seasoned debt offerings, and is highest among riskier, unknown issuers. The scarcity of research limits our understanding of the behaviors and motivations of DIPO issuers.

We would like to thank the editor, Scott Hein, and particularly the associate editor, Andrea Heuson, and the referee, Ryan Bubley, for their valuable comments and suggestions. We would also thank the participants at 2012 Southern Finance Association meetings, 2013 Midwest Finance Association meetings, and Nankai University. All errors are ours. 
In this study, we examine the roles of investor sentiment and corporate capital demands (capital market conditions) in explaining the managerial decision on DIPOs. Our research adds to the literature by being the first to document, examine, and explain variations in the aggregate volume of DIPOs using a sample of public bond issues from 1970 to 2010 .

We document that the aggregate DIPO volume displays wave patterns during the sample period. Both the number and total proceeds of DIPOs vary substantially over time, ranging from a peak of 162 ( $\$ 50.42$ billion) in 1986 to a low of 13 ( $\$ 2.23$ billion) in 1990 . Besides, we document a structural break in the DIPO volume series in October 1984. The break followed the structural change in the interest rates environment, major expansion in the new-issue speculative-grade bond market, and the adoption of the shelf registration rule (Rule 415) in the early 1980s. There was an increase in the aggregate DIPO volume in the postbreak period that was associated with a declining and low interest rates environment since mid-1984.

For the time-varying aggregate DIPO activities, we find strong support for the investor sentiment explanation, which reflects the competing nature of debt versus equity offerings as financing alternatives. Positive investor sentiment in the stock market is associated with a lower level of DIPO activities, and vice versa. Our results also show that DIPO activities increase with greater corporate demand for capital under favorable capital market conditions, and vice versa.

Blume, Keim, and Patel (1991) and Shane (1993) suggest that straight bonds can be viewed as comprising risk-free debt and equity components: the riskier the debt, the larger the equity component. These studies show that high-yield bonds behave more like equity than investment-grade bonds. In a recent study on how macroeconomic conditions affect security choice and structure in firms' financing decisions, Erel et al. (2012) find that seasoned investment-grade bond issuance is countercyclical, while seasoned highyield issuance synchronizes with the business cycle. We contribute to the understanding of the differences between investment-grade and speculative-grade issues by examining the two types of DIPO issues, respectively.

Our findings show that the IPOs of high-yield debt are procyclical while those of investment-grade debt are steady or countercyclical over the business cycle. In particular, the gross domestic product (GDP) growth rate has a statistically and economically significant positive impact on the level of high-yield DIPOs, while its impact on investment-grade DIPOs is significant and negative. The results are consistent with the postulation that poor macroeconomic and capital market conditions limit the accessibility of low-quality firms with their high-yield bond issues (Baker 2009). However, high-quality firms are able to issue investment-grade bonds, which are less information sensitive, even in challenging market conditions. In addition, we find that the volume of low-quality DIPOs is greatly affected by sentiment-driven overvaluation in the equity market. Specifically, the volume of high-yield DIPOs tends to be lower when investor sentiment in the stock market is favorable; the level of investment-grade DIPO issues is generally insulated from such sentiment.

Our results on DIPO waves and the findings of Lowry (2003) on equity IPO (EIPO) waves suggest that investor sentiment and corporate capital demands (capital market conditions) are common determinants of both waves. On the other hand, debt and equity could represent competitive financing alternatives to issuers. We further study the dynamic relation between EIPO and DIPO waves. The Granger causality test results show 
that EIPOs lead DIPOs. This causal relation is driven by the interaction between EIPOs and high-yield DIPO issues, and there is no dynamic relation between EIPO waves and investment-grade DIPO waves. The results are consistent with the postulation that highyield debt shares common features with equity.

\section{Data and Sample Statistics}

We first consider all IPOs of straight debt by U.S. firms, except those in the financial and utilities sectors, reported in the Security Data Corporation's (SDC) New Issues database. We include both public and private companies in our sample given that our research focuses on the time variations in the aggregate level of initial public debt offers by U.S. firms. For each sample firm, we only keep its first public debt offer for our DIPO sample. This yields an initial sample of 3,180 potential DIPOs issued between January 1970 and December 2010.

Since the coverage of the SDC database began in 1970, some issuers in our initial sample might have public debt offers prior to 1970 and hence do not meet the definition of a DIPO (i.e., their first public debt offering). Hence, we apply further screening for DIPOs. First, we examine Mergent Fixed Income Securities Database (FISD) to exclude firms that had outstanding public bonds before 1970 from our sample. Then, we examine the founding date of each sample firm and exclude 220 firms that were founded before $1970^{1}$ as they might have issued public debt before our sample period. Our final sample includes 2,665 DIPOs.

Table 1 reports the number, average issue size, and total dollar volume (in 2000 constant dollars) of our sample DIPOs. Echoing the fluctuating EIPO volume reported in Lowry (2003), we also note extensive variations in the level of DIPO activities over the sample period. For instance, the number of DIPO issues ranges from a low of 13 in 1990 to a high of 162 in 1986. The corresponding range of total constant dollar volume is $\$ 2.2$ billion to $\$ 50.4$ billion. Over the 41 -year sample period, a total amount of $\$ 844$ billion was raised through IPOs of straight debt by our sample firms, with an average issue size of $\$ 317$ million.

Panel A of Table 2 indicates that there is one unrated DIPO for every three rated DIPOs at the time of their issuance. There is an even split between investment-grade issues (37\%) and high-yield issues (38\%) among rated DIPOs, with B-rated bonds being the largest group, which accounts for $27 \%$ of the sample. Panel B also reports a balanced split in DIPOs that are issued by public firms (55\%) and private firms (45\%).

\section{Debt IPO Waves and Their Determinants}

It is well documented that interest rates exhibit regime-switching or structural break behaviors. For instance, Butler, Grullon, and Weston (2006) document a structural break in excess bond returns that coincided with the shift in U.S. monetary policy in the early

\footnotetext{
${ }^{1}$ We thank Jay Ritter and Laura Field for providing the founding dates for equity IPOs downloadable from Jay Ritter's website (http://bear.warrington.ufl.edu/ritter/). As a robustness check, we replicate our analysis including firms that were founded before our sample period, and obtain similar results.
} 
TABLE 1. Debt IPOs by Issue Year.

\begin{tabular}{|c|c|c|c|c|c|}
\hline Year & $\begin{array}{c}\text { No. of } \\
\text { Debt IPOs }\end{array}$ & $\%$ & $\begin{array}{l}\text { Average Proceeds } \\
\text { (Millions of } 2000 \text { \$s) }\end{array}$ & $\begin{array}{c}\text { Total Proceeds } \\
\text { (Millions of } 2000 \text { \$s) }\end{array}$ & $\%$ \\
\hline 1970 & 147 & $5.52 \%$ & 221 & 325,42 & $3.86 \%$ \\
\hline 1971 & 113 & $4.24 \%$ & 217 & 244,76 & $2.90 \%$ \\
\hline 1972 & 46 & $1.73 \%$ & 122 & 5,604 & $0.66 \%$ \\
\hline 1973 & 20 & $0.75 \%$ & 63 & 1,264 & $0.15 \%$ \\
\hline 1974 & 33 & $1.24 \%$ & 388 & 12,788 & $1.52 \%$ \\
\hline 1975 & 83 & $3.11 \%$ & 285 & 23,624 & $2.80 \%$ \\
\hline 1976 & 36 & $1.35 \%$ & 137 & 4,920 & $0.58 \%$ \\
\hline 1977 & 69 & $2.59 \%$ & 134 & 9,258 & $1.10 \%$ \\
\hline 1978 & 54 & $2.03 \%$ & 81 & 4,358 & $0.52 \%$ \\
\hline 1979 & 48 & $1.80 \%$ & 221 & 10,609 & $1.26 \%$ \\
\hline 1980 & 69 & $2.59 \%$ & 120 & 8,311 & $0.98 \%$ \\
\hline 1981 & 54 & $2.03 \%$ & 68 & 3,687 & $0.44 \%$ \\
\hline 1982 & 52 & $1.95 \%$ & 86 & 4,481 & $0.53 \%$ \\
\hline 1983 & 60 & $2.25 \%$ & 99 & 5,956 & $0.71 \%$ \\
\hline 1984 & 63 & $2.36 \%$ & 307 & 19,370 & $2.30 \%$ \\
\hline 1985 & 119 & $4.47 \%$ & 198 & 23,602 & $2.80 \%$ \\
\hline 1986 & 162 & $6.08 \%$ & 311 & 50,424 & $5.97 \%$ \\
\hline 1987 & 118 & $4.43 \%$ & 269 & 31,786 & $3.77 \%$ \\
\hline 1988 & 100 & $3.75 \%$ & 335 & 33,450 & $3.96 \%$ \\
\hline 1989 & 67 & $2.51 \%$ & 667 & 44,693 & $5.30 \%$ \\
\hline 1990 & 13 & $0.49 \%$ & 172 & 2,232 & $0.26 \%$ \\
\hline 1991 & 41 & $1.54 \%$ & 209 & 8,575 & $1.02 \%$ \\
\hline 1992 & 83 & $3.11 \%$ & 235 & 19,491 & $2.31 \%$ \\
\hline 1993 & 148 & $5.55 \%$ & 263 & 38,904 & $4.61 \%$ \\
\hline 1994 & 97 & $3.64 \%$ & 234 & 22,676 & $2.69 \%$ \\
\hline 1995 & 82 & $3.08 \%$ & 325 & 26,652 & $3.16 \%$ \\
\hline 1996 & 100 & $3.75 \%$ & 239 & 23,927 & $2.84 \%$ \\
\hline 1997 & 78 & $2.93 \%$ & 362 & 28,216 & $3.34 \%$ \\
\hline 1998 & 72 & $2.70 \%$ & 471 & 33,930 & $4.02 \%$ \\
\hline 1999 & 50 & $1.88 \%$ & 594 & 29,709 & $3.52 \%$ \\
\hline 2000 & 28 & $1.05 \%$ & 535 & 14,990 & $1.78 \%$ \\
\hline 2001 & 30 & $1.13 \%$ & 770 & 23,103 & $2.74 \%$ \\
\hline 2002 & 32 & $1.20 \%$ & 526 & 16,839 & $2.00 \%$ \\
\hline 2003 & 26 & $0.98 \%$ & 336 & 8,744 & $1.04 \%$ \\
\hline 2004 & 15 & $0.56 \%$ & 201 & 3,022 & $0.36 \%$ \\
\hline 2005 & 16 & $0.60 \%$ & 412 & 6,592 & $0.78 \%$ \\
\hline 2006 & 34 & $1.28 \%$ & 1296 & 44,065 & $5.22 \%$ \\
\hline 2007 & 39 & $1.46 \%$ & 601 & 23,429 & $2.78 \%$ \\
\hline 2008 & 26 & $0.98 \%$ & 1092 & 28,386 & $3.36 \%$ \\
\hline 2009 & 59 & $2.21 \%$ & 657 & 38,783 & $4.60 \%$ \\
\hline 2010 & 83 & $3.11 \%$ & 560 & 46,490 & $5.51 \%$ \\
\hline Total & 2,665 & $100.00 \%$ & 317 & 843,960 & $100.00 \%$ \\
\hline
\end{tabular}

Note: A sample of initial public offerings (IPOs) of corporate straight bonds issued during the 41-year sample period, 1970 to 2010, is obtained from the Security Data Corporation database. The sample is then cross-checked with the Mergent Fixed Income Securities Database (FISD) to verify that the issuing firms did not have any preexisting public straight debt outstanding. Average proceeds and total proceeds (in millions) for each debt IPO are expressed in 2000 constant dollars (adjusted using the Consumer Price Index). 
TABLE 2. Frequency Distribution of DIPOs.

\begin{tabular}{lcc}
\hline Descriptive Variable & No. of DIPOs & Percentage \\
\hline Panel A. Frequency Distribution of Initial Public Bond Offers by Standard \& Poor's Bond Ratings \\
\hline AAA & 62 & $2.33 \%$ \\
AA & 118 & $4.43 \%$ \\
A & 359 & $13.47 \%$ \\
BBB & 444 & $16.66 \%$ \\
BB & 189 & $7.09 \%$ \\
B & 724 & $27.17 \%$ \\
CCC & 106 & $3.98 \%$ \\
NR & 663 & $24.88 \%$ \\
\hline
\end{tabular}

Panel B. Whether the DIPO Firm Is a Public Firm at the Time of DIPO

\begin{tabular}{lll}
\hline Public firm at the time of DIPO & 1,464 & $54.93 \%$ \\
Private firm at the time of DIPO & 1,202 & $45.07 \%$ \\
\hline
\end{tabular}

Note: A sample of initial public offerings of corporate straight bonds issued during the 41-year sample period, 1970 to 2010, is obtained from the Security Data Corporation database. The sample is then cross-checked with the Mergent Fixed Income Securities Database (FISD) to verify that the issuing firms did not have any preexisting public straight debt outstanding. Average proceeds and total proceeds (in millions) for each debt initial public offering (DIPO) are expressed in 2000 constant dollars (adjusted using the Consumer Price Index).

1980s. Because the cost of debt financing is driven by the riskiness of the issuer as well as the general interest rate level, DIPO volume could also exhibit structural breaks over our sample period. We employ Andrews and Ploberger's (1994) standard change point tests for structural breaks in our monthly DIPO volume series. We report the results on the unconditional mean of the series in Table 3. The results show that the null hypothesis that DIPO volumes remained constant over the sample period is rejected at the $1 \%$ level. We identify October 1984 as the structural break in the DIPO volume series. The structural break could be explained by the steady decline in interest and inflation rates that followed major changes in the monetary policy in the United States in the 1980s. The structural point also follows the introduction of the shelf registration rule (Rule 415) in May 1982. Rule 415, which is mostly used for public debt financing, provides flexibility to issuing firms in timing their offers within the 24-month shelf period without further extensive registration requirements.

In the following sections, we postulate two sets of determinants to explain issuing firms' debt IPO decisions: (1) corporate capital demands and capital market conditions and (2) investor sentiment. We first define the aggregate proxies for the determinants and discuss their descriptive statistics, which are reported in Table 4.

\section{Corporate Capital Demands and Capital Market Conditions}

Recent studies on the influence of macroeconomic conditions on firms' financing decisions show that aggregate demands for capital (Lowry 2003) and stock market conditions (Pastor and Veronesi 2005) explain variations in EIPO volume over time. Erel et al. (2012) argue that the supply of external capital is more abundant as investors are less risk averse under favorable economic and capital market conditions. Because public debt 
TABLE 3. Structural Break Tests.

\begin{tabular}{|c|c|c|c|c|}
\hline \multicolumn{2}{|c|}{ Andrews-Quandt } & \multirow[b]{2}{*}{ Date } & \multicolumn{2}{|c|}{ Andrews-Ploberger } \\
\hline Test & $p$-value & & Test & $p$-value \\
\hline 23.815 & .000 & $1984: 10$ & 8.674 & .000 \\
\hline
\end{tabular}

provides increased liquidity, flexibility, and borrowing capacity to the issuing firm and the avoidance of holdup by private lenders (Rajan 1992), we postulate that a firm is more likely to access the public debt market when there is higher demand for and supply of capital during favorable capital market conditions. In the examination of variations in the monthly DIPO volume, we use four variables to proxy for the aggregate demands for capital and capital market conditions: aggregate GDP growth rate (GDP_Growth), valueweighted Center for Research in Security Prices (CRSP) index return ( $\left.V W_{-} R e t\right)$, Term_Spread, and the lagged volume of EIPOs (Lagged_EIPOS), We obtain the macroeconomic data from the website of the Federal Reserve Bank of St. Louis (http:// research.stlouisfed.org/fred2/).

We compute monthly GDP_Growth by dividing the percentage change in real GDP in the previous quarter by 3 . In general, high GDP_Growth is associated with economic upswings and a favorable business climate, which likely coincides with increases in investment opportunities. These optimistic market conditions would lead to greater corporate demands for external capital to finance positive net present value (NPV) projects during economic expansions, and vice versa. We expect that rising aggregate demands for capital, which are associated with economic growth, will also have a positive impact on the level of DIPO activities. Table 4 reports that the U.S. economy grew at an average annual rate of approximately $3 \%$ over the entire sample period, as well as within each of the two subperiods before and after the structural break (October 1984) in the DIPO volume series.

We compute $V W_{-}$Ret with the concurrent monthly return on the CRSP valueweighted stock index, and use it to proxy for the stock market condition. VW_Ret is a procyclical variable and is recognized as a leading indicator of macroeconomic prospects. A favorable stock market environment may encourage corporate financing activities in two dimensions. In the first dimension, the rising stock prices may be driven by an increase in investment opportunities, leading to rising demands for capital. Loughran, Ritter, and Rydqvist (1994) find that EIPO volume tends to be higher when the stock market is higher. Baker and Wurgler (2002) show that firms issue equity when they are overvalued by irrational investors, who do not revise their valuations to reflect the information conveyed by the equity issue.

In the second dimension, while rising demands for capital could generally have a positive effect on DIPO activities, lower costs of equity capital that are associated with higher stock prices might have a negative impact on the attractiveness of public debt as an 
TABLE 4. Descriptive Statistics.

\begin{tabular}{|c|c|c|c|c|c|c|c|c|c|c|c|c|}
\hline & \multicolumn{4}{|c|}{ Entire Sample Period } & \multicolumn{4}{|c|}{ 1970:1-1984:9 } & \multicolumn{4}{|c|}{ 1984:10-2010:12 } \\
\hline & Mean & Std & Min & Max & Mean & Std & Min & Max & Mean & Std & Min & Max \\
\hline \multicolumn{13}{|c|}{ Economic expansion variables } \\
\hline GDP_Growth (\%) & 0.23 & 0.29 & -0.77 & 1.31 & 0.25 & 0.40 & -0.68 & 1.31 & 0.22 & 0.21 & -0.77 & 0.65 \\
\hline$V W_{-} \operatorname{Ret}(\%)$ & 0.92 & 4.68 & -22.54 & 16.56 & 0.87 & 4.80 & -12.07 & 16.56 & 0.95 & 4.61 & -22.54 & 12.85 \\
\hline Term_Spread $(\%)$ & 1.31 & 1.48 & -4.00 & 4.55 & 0.75 & 1.71 & -4.00 & 3.93 & 1.63 & 1.23 & -0.89 & 4.55 \\
\hline Lagged_EIPOs & 3.66 & 4.32 & 0.00 & 32.96 & 4.26 & 6.34 & 0.00 & 32.96 & 3.32 & 2.53 & 0.00 & 12.01 \\
\hline \multicolumn{13}{|c|}{ Investor sentiment variables } \\
\hline $\log B M$ & -0.16 & 0.20 & -0.57 & 0.20 & 0.06 & 0.06 & -0.08 & 0.20 & -0.28 & 0.14 & -0.57 & 0.03 \\
\hline Yield_Spread $(\%)$ & 1.11 & 0.47 & 0.55 & 3.38 & 1.32 & 0.50 & 0.61 & 2.69 & 1.00 & 0.41 & 0.55 & 3.38 \\
\hline$V W \_S t d(\%)$ & 0.89 & 0.53 & 0.28 & 4.98 & 0.78 & 0.31 & 0.34 & 2.10 & 0.95 & 0.62 & 0.28 & 4.98 \\
\hline
\end{tabular}

Note: This table provides descriptive statistics on the explanatory variables used in the time-series regressions. For each variable, the mean, standard deviation, and maximum and minimum values are calculated. GDP_Growth is computed by dividing the percentage change in real gross domestic product in the previous quarter by 3 . VW_Ret is the concurrent monthly return on the Center for Research in Security Prices (CRSP) value-weighted stock index. Term_Spread is the difference in the yields of 10-year Treasury bond and Treasury bill. Lagged_EIPOs is the number of equity initial public offerings in the previous month deflated by the number of public firms (in thousands) at the end of the prior month. $\log B M$ is the logarithm of the book-to-market ratio of the S\&P 500 index in the previous month. Yield_Spread is the difference in the yield on Moody's Baa-rated bonds and on Aaa-rated bonds. $V W \_S t d$ is the monthly stock return standard deviation that is computed from daily value-weighted CRSP stock returns.

alternate financing source. Dittmar and Thakor (2007) show that firms issue equity when their stock prices are high, but either issue debt or no security when their stock prices are low. As such, the net effect of stock market return $\left(V W_{-} R e t\right)$ on the decision to issue public debt, and hence the DIPO volume, is an empirical issue. Table 4 indicates that the average monthly stock market return was $0.92 \%$ for entire sample period. Stock returns were higher in the postbreak period during the declining and low interest rates environment than in the prebreak period, when interest rates double-peaked in late 1981 and mid-1984.

We use Term_Spread, which is the difference in the yields of 10-year Treasury bonds and Treasury bills, to proxy for bond market conditions (Fama and French 1989). Assuming the long-term firm value maximization objective, firms will evaluate their current and future demands for capital and the associated costs of capital in their selection of funding sources. Issuing firms may lock in lower interest rates by seeking external long-term debt capital if they anticipate rising borrowing costs as the economy expands. Hence, a higher term spread may imply market expectation of rising future interest and inflation rates, which are typically associated with an economic expansion (Mizen, Tsoukalas, and Tsoukas 2009). Thus, we postulate a positive association between Term_Spread and the level of DIPO activities. Table 4 reports that the average term spread was $1.31 \%$ over the entire sample period.

Last, we include Lagged_EIPOs, which is the number of EIPOs in the previous month deflated by the number of public firms (in thousands) at the end of the prior month, to proxy for the level of capital demands (Lowry 2003). We postulate that a higher number of EIPOs has a positive impact on the level of DIPOs. Table 4 reports that Lagged_EIPOs was 3.66 over the entire sample period, which was higher in the pre-1984 period than that in the post-1984 period. 


\section{Investor Sentiment}

The empirical findings in the behavioral finance literature suggest that investor sentiment affects the external financing activities of corporations. The investor sentiment explanation postulates that overvaluation of issuing firms is likely to occur when investors are overly optimistic about firm value, which would lower the cost of financing. Empirical findings show that investor sentiment affects the level of EIPO volume as issuing firms take advantage of positive market conditions when their firms are being overvalued during periods of elevated sentiment (Lowry 2003). McLean and Zhao (2011) find that the level of external financing, both debt and equity, is higher in an economic expansion and investor sentiment is favorable. We postulate that investor sentiment also helps explain fluctuations in DIPO activities over time. We use three measures for investor sentiment: logarithm of book-to-market ratio $(\log B M)$, Yield_Spread, and standard deviation of the value-weighted CRSP index return $\left(V W \_S t d\right)$.

Empirical evidences on equity offerings show that investor sentiment improves when investors become less risk averse and hence are more willing to invest in risky securities that lift issuing firms' market values relative to their fundamental values (Choe, Masulis, and Nanda 1993; Loughran and Ritter 1995; Jung, Kim, and Stulz 1996; Korajczyk and Levy 2003). Firms often time their equity offers to take advantage of their stocks being overvalued, which can result from investors being overly optimistic during stock market run-ups (Myers and Majluf 1984; Lamont and Stein 2006). We use the $\log B M$ variable, which is computed by taking the logarithm of the book-to-market ratio of the S\&P 500 index in the previous month, ${ }^{2}$ to measure the extent of overvaluation as a proxy for investor sentiment. To the extent that favorable investor sentiment is shared across capital market segments, we expect a negative association between $\log B M$ and DIPO volume (McLean and Zhao 2011). On the other hand, both debt and equity financing are major funding sources for companies. As such, a favorable investor sentiment in the stock market could draw both issuers and investors to the equity market and away from the debt market. In this case, the substitution effect dominates, which leads to a positive impact of $\log B M$ on DIPO volume. As such, the impact of $\log B M$ on DIPO volume is an empirical issue. ${ }^{3}$

Nayak (2010) finds that bonds appear underpriced during low-sentiment periods, which can lead to higher yields; they are likely overpriced when they are associated with lower yields when investor optimism reigns. Furthermore, Nayak reports that sentimentdriven mispricing is more severe among high-yield bonds. His findings suggest a negative relation between investor sentiment and corporate bond yield spreads. We define Yield_Spread as the difference in the yield on Moody's Baa-rated bonds and on Aaa-rated bonds for the same month of the DIPO volume. Yield_Spread is likely larger during lowsentiment periods because sentiment-driven investors become more risk averse and hence

\footnotetext{
${ }^{2}$ We thank Robert Shiller for allowing us to download monthly aggregate market value of the S\&P 500 index data from his website (http://www.econ.yale.edu/ shiller/). We use the accounting clean surplus rule to compute the aggregate book value of the S\&P 500 index (Vuolteenaho 2002).

${ }^{3}$ The empirical literature that documents relations between the aggregate market-to-book ratio and timevarying risk (Fama and French 1992, 1993), and business cycles (Liew and Vassalou 2000), also suggests a possible positive impact of $\log B M$ on the DIPO volume.
} 
demand greater compensation for risk taking. In addition, Shen and $\mathrm{Yu}$ (2012) argue that equity is likely overpriced during high-sentiment periods and fairly priced otherwise. Because firms are motivated to take advantage of stock overvaluation with equity offers during high-sentiment periods but use debt offers when their stock prices are low during low-sentiment periods (Dittmar and Thakor 2007), we postulate a positive relation between Yield_Spread and DIPO volume.

Shalen (1993) and Gao, Connie, and Zhong (2006) link higher stock return volatility directly to greater divergence in investor opinions on stock valuation. We use stock market return volatility, $V W \_S t d$, which is the monthly standard deviation of stock returns, computed from the daily CRSP value-weighted stock index returns, to measure the divergence in investor opinions on firm valuation. High levels of divergence in investor opinions could induce optimistic biases in stock valuation with the existence of short-sale restrictions (Miller 1977). Because the impact of pessimistic investor sentiment on valuation is limited by the short-sale restrictions, stock prices likely reflect the dominating view of optimistic investors, which leads to overvaluation when there is greater divergence in investor opinions. Issuing firms are motivated to choose overvalued equity over debt under such circumstances. Hence, we postulate a negative relation between stock market volatility $\left(V W \_S t d\right)$ and the level of DIPO activities.

On the other hand, Merton (1987) shows that higher levels of investor disagreement on stock valuation are associated with a greater degree of information asymmetry in stock market. The higher adverse selection costs of equity financing associated with greater information asymmetry could induce issuing firms to seek debt financing, which has lower adverse selection costs, as an alternate financing source. Hence, greater stock market volatility could have a positive impact on DIPO volume.

\section{Results}

We examine the time variations in DIPO volume using the two sets of explanatory variables: corporate capital demands and investor sentiment. We incorporate the structural break in the monthly DIPO volume series by including a dummy variable, YDummy, in all regressions. YDummy equals 1 for the postbreak period, which starts with October 1984, and 0 otherwise.

We first use Pearson correlation analysis to examine whether there is multicollinearity among the explanatory variables by analyzing the degree of the correlations (Table 5). The $\log B M$ variable is significantly and positively correlated with Yield_Spread. Because $\log B M$ uses equity market information to measure investor sentiment while Yield_Spread captures investor sentiment with debt market information, their highly positive correlation could be explained by shared favorable investor sentiment that prevails across capital market segments. The modest to moderate magnitude of the correlation coefficients between other variables does not suggest the presence of collinearity among the explanatory variables. Because the collinearity problem may vary across our sample period, we also apply Pearson correlation analysis 
TABLE 5. Pearson Correlation Coefficients.

\begin{tabular}{lccccccc}
\hline & GDP_Growth & VW_Ret & Term_Spread & Lagged_EIPOS & logBM & Yield_Spread & VW_Std \\
\hline GDP_Growth & 1.00 & 0.07 & 0.13 & 0.23 & -0.06 & -0.33 & -0.32 \\
& & $(.14)$ & $(.00)$ & $(<.0001)$ & $(.16)$ & $(<.0001)$ & $(<.0001)$ \\
VW_Ret & 1.00 & 0.07 & 0.00 & 0.07 & 0.06 & -0.34 \\
& & & $(.15)$ & $(.99)$ & $(.14)$ & $(.19)$ & $(<.0001)$ \\
Term_Spread & & 1.00 & 0.07 & -0.09 & 0.17 & 0.04 \\
& & & $(.14)$ & $(.04)$ & $(.00)$ & $(.40)$ \\
Lagged_EIPOS & & & 1.00 & -0.08 & -0.23 & -0.21 \\
& & & & $(.09)$ & $(<.0001)$ & $(<.0001)$ \\
logBM & & & & 1.00 & 0.50 & -0.17 \\
& & & & & $(<.0001)$ & $(.00)$ \\
Yield_Spread & & & & & & & \\
& & & & & & & $(<.00001)$ \\
VW_Std & & & & & & & \\
\end{tabular}

Note: GDP_Growth is computed by dividing the percentage change in real gross domestic product in the previous quarter by 3. VW_Ret is the concurrent monthly return on Center for Research in Security Prices (CRSP) valueweighted stock index. Term_Spread is the difference in the yields of 10-year Treasury bond and Treasury bill. Lagged_EIPOs is the number of equity initial public offerings in the previous month deflated by the number of public firms (in thousands) at the end of the prior month. $\log B M$ is the logarithm of the book-to-market ratio of the S\&P 500 index in the previous month. Yield_Spread is the difference in the yield on Moody's Baa-rated bonds and on Aaa-rated bonds. VW_Std is the monthly stock return standard deviation that is computed from daily valueweighted CRSP stock returns. The $p$-values are reported in parentheses.

for the subperiods, both before and after the structural breakpoint in the DIPO volume series. We find no evidence of a collinearity problem in either subperiod. ${ }^{4}$

We follow Polk, Thompson, and Vuolteenaho (2006) and examine the potential impact of outliers and nonstationary issues in the DIPO volume data. Specifically, we use an ordinal composite measure (Rank_Proceeds) by transforming the total proceeds of DIPOs into a composite rank, assigning higher total proceeds with higher ranks. Table 6 reports our regression results on the time-series analysis of the monthly Rank_Proceeds over the entire sample period. Models 1-3 in Table 6 report the regression results on the roles of the corporate capital demands and investor sentiment in explaining firms' decisions to access the public debt market, respectively. Models 4 and 5 report the results for both sets of determinants.

\section{The Overall Sample}

Model 1 in Table 6 reports the regression results regarding the roles of corporate demands for capital and capital market conditions in explaining variations in monthly DIPO volume. In general, corporate demands for capital and favorable capital market conditions have a positive impact on the level of DIPO activities. The positive and statistically significant coefficient of the $V W_{-}$Ret variable indicates that an increase in stock market return has a positive impact on the number of DIPOs. Thus, the income effect of

\footnotetext{
${ }^{4}$ We also use the Variance Inflation Index and the Collinearity options in SAS's regression procedure to detect multicollinearity problems and find that multicollinearity is not a concern among the explanatory variables.
} 
TABLE 6. Monthly Time-Series Analysis of Debt IPO.

\begin{tabular}{|c|c|c|c|c|c|}
\hline & Model 1 & Model 2 & Model 3 & Model 4 & Model 5 \\
\hline \multirow[t]{2}{*}{ Intercept } & $0.32^{* * *}$ & $0.45^{* * *}$ & $0.40^{* * *}$ & $0.35^{* * *}$ & $0.31^{* * *}$ \\
\hline & $(12.56)$ & $(15.70)$ & $(9.40)$ & $(8.99)$ & $(5.57)$ \\
\hline \multirow[t]{2}{*}{ GDP_Growth } & 2.90 & & & 2.06 & 2.42 \\
\hline & $(0.67)$ & & & $(0.45)$ & $(0.51)$ \\
\hline \multirow[t]{2}{*}{$V W \_R e t$} & $0.62^{* *}$ & & & 0.34 & 0.26 \\
\hline & $(2.36)$ & & & (1.24) & $(0.91)$ \\
\hline \multirow[t]{2}{*}{ Term_Spread } & $2.15^{* *}$ & & & $1.67^{*}$ & $1.64^{*}$ \\
\hline & $(2.45)$ & & & $(1.81)$ & $(1.73)$ \\
\hline \multirow[t]{2}{*}{ Lagged_EIPOs } & $0.01^{* * *}$ & & & $0.01^{* * *}$ & $0.01^{* * *}$ \\
\hline & $(3.38)$ & & & $(3.53)$ & $(3.32)$ \\
\hline \multirow[t]{2}{*}{$\log B M$} & & $0.19^{*}$ & & $0.25^{* *}$ & \\
\hline & & (1.89) & & $(2.25)$ & \\
\hline \multirow[t]{2}{*}{ Yield_Spread } & & & $6.41^{* *}$ & & $6.65^{*}$ \\
\hline & & & (2.10) & & $(1.87)$ \\
\hline \multirow[t]{2}{*}{$V W \_S t d$} & & $-8.61^{* * *}$ & $-11.25^{* * *}$ & $-5.36^{* *}$ & $-8.53^{* * *}$ \\
\hline & & $(-3.67)$ & $(-4.37)$ & $(-2.02)$ & $(-3.01)$ \\
\hline \multirow[t]{2}{*}{ YDummy } & $0.15^{* * *}$ & $0.24^{* * *}$ & $0.20^{* * *}$ & $0.25^{* * *}$ & $0.19^{* * *}$ \\
\hline & $(5.68)$ & $(5.58)$ & $(7.07)$ & $(5.11)$ & $(6.01)$ \\
\hline$N$ & 491 & 491 & 491 & 491 & 491 \\
\hline Adj. $R^{2}$ & 0.12 & 0.10 & 0.10 & 0.13 & 0.13 \\
\hline
\end{tabular}

Note: This table reports time-series regressions at the monthly interval. The dependent variable is Rank_Proceeds, which is an ordinal composite measure by transforming the total proceeds of debt initial public offerings (IPOs) into a composite rank between 0 and 1, assigning higher total proceeds with higher ranks. GDP_Growth is computed by dividing the percentage change in real gross domestic product in the previous quarter by 3 . VW_Ret is the concurrent monthly return on the Center for Research in Security Prices (CRSP) value-weighted stock index. Term_Spread is the difference in the yields of 10-year Treasury bond and Treasury bill. Lagged_EIPOs is the number of equity IPOs in the previous month deflated by the number of public firms (in thousands) at the end of the prior month. $\log B M$ is the logarithm of the book-to-market ratio of the S\&P 500 index in the previous month. Yield_Spread is the difference in the yield on Moody's Baa-rated bonds and on Aaa-rated bonds. VW_Std is the monthly stock return standard deviation that is computed from daily value-weighted CRSP stock returns. YDummy is a dummy variable that equals 1 if the debt IPO was issued in 1984:10 or later, 0 otherwise. The $t$-statistics are reported in parentheses.

*** Significant at the $1 \%$ level.

** Significant at the $5 \%$ level.

* Significant at the $10 \%$ level.

increasing demands for capital is probably stronger than the substitution effect of lower costs of equity capital on the demand for debt capital that is due to stock market run-ups. The positive coefficient for GDP_Growth also suggests that economic expansions attract more firms seeking external debt capital for financing investment opportunities.

The Term_Spread variable, which reflects the term structure of interest rates, has a positive and statistically significant coefficient. As a higher term spread implies anticipation of higher future interest rates, the positive coefficient is consistent with the postulation that corporations lock in the relatively low rates when they anticipate rising borrowing costs.

The coefficient on the lagged_EIPOs variable is also positive and statistically significant. This is consistent with the argument that a large number of firms going public are associated with greater demands for capital. Higher capital demands lead firms to seek more flexible and liquid ways to finance. Compared to private debt, public debt provides a large borrowing capacity, added flexibility, and liquidity. Hence, more firms enter the public debt market for the first time when their financing needs are high. 
Models 2 and 3 in Table 6 report the regression results on the roles of investor sentiment in explaining variations in Rank_Proceeds. The presence of collinearity between $\log B M$ and Yield_Spread precludes us from including both variables in the same regression. In Model 2, we include the $\log B M$ and $V W_{-} S t d$ variables, and we replace $\log B M$ with Yield_Spread in Model 3. The statistically significant positive coefficient of the $\log B M$ variable in Model 2 indicates that there is limited support for the postulation that the favorable impact of investor sentiment on financing activities applies to both the equity market and the debt market. Instead, it is consistent with the postulation that equity and debt are competing funding sources (i.e., issuers are attracted to the public equity market when investor sentiment indicates an overvaluation of equity issues). This situation leads to a lower level of DIPOs. On the other hand, as investor sentiment cools in the equity market, investors and issuers are attracted to the debt market, which leads to an increase in DIPO activities. The significant positive coefficient for Yield_Spread in Model 3 also supports the investor sentiment explanation for variations in monthly DIPO volume.

Models 2 and 3 in Table 6 show that the stock market volatility ( $V W \_S t d$ ) variable has statistically and economically significant negative coefficients, which are consistent with the postulation that debt and equity are competing funding sources for issuers. A divergence in investor opinions in the stock market may induce optimistic biases in stock valuation that encourage firms to issue overvalued equity. Given the competing nature of equity and debt financing, the favorable stock valuation that is associated with investor disagreement could negatively affect the level of DIPO activities. ${ }^{5}$

Models 4 and 5 in Table 6 report the results from the comprehensive regressions that examine the roles of both corporate capital demands and investor sentiment variables in explaining firms' decisions to access the public debt market. The results are consistent with those reported in Models 1-3 that the Lagged_EIPOs, $\log B M$, and VW_Std variables are statistically significant in explaining variations in the aggregate level of DIPOs. ${ }^{6}$ In addition, the YDummy variable has a positive and statistically significant coefficient across all regressions, which is consistent with the DIPO proceeds reported in Table 1. This result echoes the general upward trend in public seasoned debt issues during the declining interest rates era starting in mid-1980s (Erel et al. 2012). Overall, the results suggest that investor sentiment plays a large role in explaining the DIPO waves.

\section{Speculative versus Investment Issues}

Given the distinctive financing patterns of issuers with different credit quality (Blume, Keim, and Patel 1991; Shane 1993; Datta, Datta, and Patel 1997), we further examine the determinants of investment-grade versus high-yield-grade DIPO issues over

\footnotetext{
${ }^{5}$ The "flight to quality" explanation (Caballero and Krishnamurthy 2008) suggests that an increase in perceived uncertainty in capital markets as proxied by stock market volatility could discourage risk-averse investors' demand for risky securities. Such cautious investor sentiment could dampen the supply of capital, especially to lower quality issuers, and hence a lower overall level of DIPOs. Hence, the negative coefficient of the VW_Std variable is also consistent with the "flight to quality" explanation. This finding also echoes the negative impact of increasing volatility on the level of equity IPO activities documented in Pastor and Veronesi (2005).

${ }^{6}$ The Term_Spread (Yield_Spread) variable becomes marginally significant with the inclusion of investor sentiment (capital market conditions) variables.
} 
TABLE 7. Monthly Time-Series Analysis of High-Yield DIPOs and Investment-Grade DIPOs.

\begin{tabular}{|c|c|c|c|c|}
\hline & \multicolumn{2}{|c|}{ High-Yield DIPOs } & \multicolumn{2}{|c|}{ Investment-Grade DIPOs } \\
\hline & Model 1 & Model 2 & Model 3 & Model 4 \\
\hline Intercept & $\begin{array}{l}0.36^{* * *} \\
(9.76)\end{array}$ & $\begin{array}{l}0.37^{* * *} \\
(6.89)\end{array}$ & $\begin{array}{c}0.45^{* * *} \\
(11.02)\end{array}$ & $\begin{array}{l}0.42^{* * *} \\
(7.20)\end{array}$ \\
\hline GDP_Growth & $\begin{array}{l}15.15^{* * *} \\
(3.49)\end{array}$ & $\begin{array}{l}10.84^{* *} \\
(2.33)\end{array}$ & $\begin{array}{l}-9.88^{* *} \\
(-2.05)\end{array}$ & $\begin{array}{c}-7.44 \\
(-1.50)\end{array}$ \\
\hline$V W \_R e t$ & $\begin{array}{c}-0.07 \\
(-0.26)\end{array}$ & $\begin{array}{l}-0.10 \\
(-0.34)\end{array}$ & $\begin{array}{l}1.14^{* * *} \\
(3.93)\end{array}$ & $\begin{array}{l}1.10^{* * *} \\
(3.70)\end{array}$ \\
\hline Term_Spread & $\begin{array}{c}0.93 \\
(1.08)\end{array}$ & $\begin{array}{c}2.20^{* *} \\
(2.36)\end{array}$ & $\begin{array}{c}0.85 \\
(0.88)\end{array}$ & $\begin{array}{c}0.17 \\
(0.17)\end{array}$ \\
\hline Lagged_EIPOs & $\begin{array}{l}0.02^{* * *} \\
(6.22)\end{array}$ & $\begin{array}{l}0.01^{* * *} \\
(4.36)\end{array}$ & $\begin{array}{c}0.00 \\
(-1.04)\end{array}$ & $\begin{array}{c}0.00 \\
(-0.39)\end{array}$ \\
\hline $\log B M$ & $\begin{array}{l}0.78^{* * *} \\
(7.38)\end{array}$ & & $\begin{array}{l}-0.26^{* *} \\
(-2.17)\end{array}$ & \\
\hline Yield_Spread & & $\begin{array}{c}7.42^{* *} \\
(2.13)\end{array}$ & & $\begin{array}{c}0.07 \\
(0.02)\end{array}$ \\
\hline$V W \_S t d$ & $\begin{array}{l}-8.85^{* * *} \\
(-3.55)\end{array}$ & $\begin{array}{l}-14.62^{* * *} \\
(-5.26)\end{array}$ & $\begin{array}{c}3.16 \\
(1.14)\end{array}$ & $\begin{array}{c}4.29 \\
(1.45)\end{array}$ \\
\hline YDummy & $\begin{array}{l}0.36^{* * *} \\
(7.69)\end{array}$ & $\begin{array}{l}0.10^{* * *} \\
(3.34)\end{array}$ & $\begin{array}{c}-0.02 \\
(-0.33)\end{array}$ & $\begin{array}{c}0.08^{* *} \\
(2.33)\end{array}$ \\
\hline$N$ & 491 & 491 & 491 & 491 \\
\hline Adj. $R^{2}$ & 0.24 & 0.16 & 0.06 & 0.05 \\
\hline
\end{tabular}

Note: This table shows time-series regressions at the monthly interval. The respective dependent variables are the ordinal composite measures, Rank_Proceeds_HY and Rank_Proceeds_IG, which are computed by transforming the total proceeds of high-yield-grade and investment-grade debt initial public offerings (DIPOs) into a composite rank, respectively. GDP_Growth is computed by dividing the percentage change in real gross domestic product in the previous quarter by 3.VW_Ret is the concurrent monthly return on the Center for Research in Security Prices (CRSP) value-weighted stock index. Term_Spread is the difference in the yields of 10-year Treasury bond and Treasury bill. Lagged_EIPOs is the number of equity IPOs in the previous month deflated by the number of public firms (in thousands) at the end of the prior month. $\log B M$ is the logarithm of the book-to-market ratio of the S\&P 500 index in the previous month. Yield_Spread is the difference in the yield on Moody's Baa-rated bonds and on Aaa-rated bonds. VW_Std is the monthly stock return standard deviation that is computed from daily value-weighted CRSP stock returns. YDummy is a dummy variable that equals 1 if the DIPO is issued in 1984:10 or later, 0 otherwise. The $t$ statistics are reported in parentheses.

*** Significant at the $1 \%$ level.

${ }^{* *}$ Significant at the $5 \%$ level.

our entire sample period. Table 7 reports the regression results of the comprehensive model that includes both sets of explanatory variables for investment-grade issues and high-yield-grade issues. For investment-grade issues, the dependent variable is the ordinal composite measure, Rank_Proceeds_IG, which is computed by transforming the total proceeds of investment-grade DIPOs into a composite rank. We apply the same procedures to construct the ordinal dependent variable (Rank_Proceeds_HY) for the speculative-grade DIPOs sample separately. Figure I shows the stacked plot graphs of Rank_Proceeds, Rank_Proceeds_IG, and Rank_Proceeds_HY.

We find that issue quality plays a role in explaining time variations in DIPO volume over time and business cycles. The statistically significant positive coefficients of GDP_Growth and Lagged_EIPOs in Table 7, which only apply to high-yield issues, point to the procyclicality of DIPO activities of low-quality issuers. On the other hand, the 


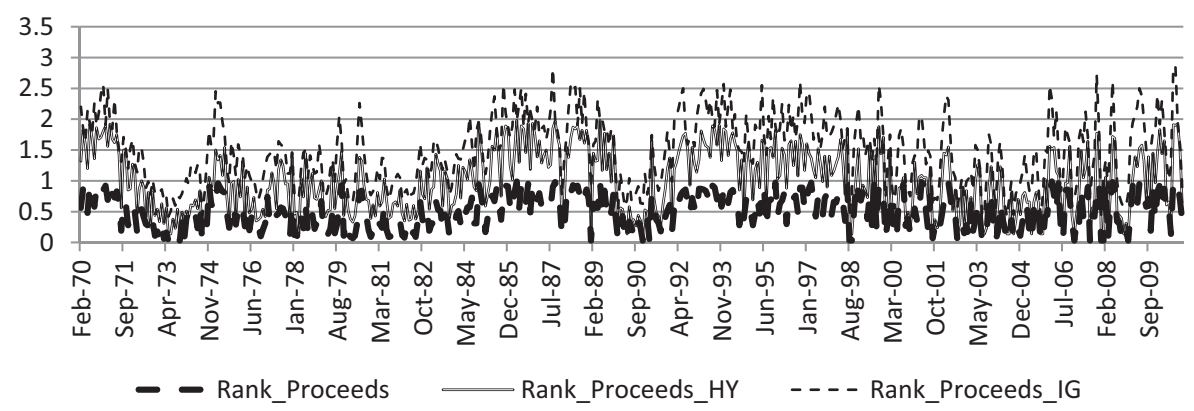

Figure I. Stacked Plot Graph of Dependent Variables. This is a stacked plot graph of three dependent variables. Rank_Proceeds is the dependent variable in Table 6. It is an ordinal composite measure by transforming the total proceeds of debt IPOs into a composite rank between 0 and 1, assigning higher total proceeds with higher ranks. Rank_Proceeds_HY and Rank_Proceeds_IG are dependent variables in Table 7, which are computed by transforming the total proceeds of high-yield-grade and investment-grade debt IPOs into a composite rank separately.

negative coefficients of these two variables for investment-grade issues indicate that DIPO activities of quality issuers are steady or countercyclical. In sum, the regression results on the corporate capital demands variables are consistent with Erel et al. (2012), who find that the accessibility of quality issuers to public debt capital is less sensitive to the phase of business cycles, while low-quality issuers typically access public debt capital when market conditions are favorable.

Table 7 also reports contrasting results on the investor sentiment variables for the two DIPO samples. While the coefficients for both $\log B M$ and Yield_Spread are significant and positive for high-yield issues, $\log B M$ has a significant negative coefficient for investment-grade issues. Furthermore, Table 7 reports a significant negative impact of stock market volatility on the level of high-yield DIPOs, but an insignificant positive impact on investment-grade issues. This result is consistent with the notion that sentiment-driven overvaluation in the equity market has a stronger adverse impact on the level of lower quality DIPO issues than on higher quality issues. The distinctive contrasts between the two classes of DIPOs suggest that high-yield issues are close substitutes to equity issues and hence are sensitive to investor sentiment, while investment-grade DIPO issues are generally insulated from such sentiment.

\section{Debt IPO Waves versus Equity IPO Waves}

Consistent with the postulation that both debt and equity are major instruments used by firms to raise external funding while they could also be competitive financing sources, our regression results on $\log B M$, Lagged_EIPOs, and $V W \_S t d$ indicate that there are common factors explaining the DIPO waves and the EIPO waves, as well as differences between the two waves. We conduct a Granger causality test to examine the dynamic relations between time variations in the levels of DIPOs and EIPOs to further our understanding of the dynamics between the two IPO waves. The Granger causality test examines whether the aggregate level of EIPOs, that is, the constant dollar monthly total EIPO proceeds, helps better predict the aggregate level of DIPOs, that is, the constant dollar monthly total DIPO proceeds, in the presence of its lagged values, and vice versa. 
We implement three sets of Granger causality tests with an optimal lag length of 3 using the Akaike information criterion. We find that EIPOs lead DIPOs but that there is no evidence of DIPOs leading EIPOs in the overall sample. Given the differences between high-yield and investment-grade bonds, we further examine the lead-lag relations between EIPOs and the two classes of DIPOs, respectively. We find a similar pattern that EIPO volume leads high-yield DIPO volume and there is no inverse causality for the highyield DIPOs sample. On the other hand, the results show no causality between investment-grade DIPO waves and EIPO waves. In sum, the Granger causality test results show a dynamic relation between EIPO waves and DIPO waves with EIPOs leading DIPOs, which is driven by high-yield DIPO issues. The results echo the empirical evidence on the similarity between high-yield debt and equity. ${ }^{7}$

\section{v. Conclusion}

Successful DIPOs give the issuers access to the enormous public debt market as a primary financing alternative to private debt placement and public equity capital. Our research contributes to the scant literature on DIPOs by being the first study to examine the aggregate DIPO activities from 1970 to 2010. We are the first to document DIPO waves: both the number of DIPOs and the total proceeds raised in these offerings vary substantially over time. In addition, we document a structural break in the aggregate DIPO volume, which displays upward momentum following the structural change in the interest rates environment, the major expansion of new-issue speculative-grade bonds market, and the adoption of the shelf registration rule (Rule 415) in the early 1980s. Regardless, DIPO waves are observed in both the pre-1984 and post-1984 subperiods.

In exploring possible explanations for DIPO waves, we show that investor sentiment and corporate capital demands play significant roles in explaining the time variations in DIPO volume. Lower levels of stock market volatility and equity valuation are associated with a higher level of DIPO volume. DIPO volume also tends to rise in economic expansions and favorable capital market conditions, and vice versa. These findings echo those on EIPO waves documented in the literature.

Our findings indicate distinctive differences in the variations of high-yield DIPO issues versus investment-grade DIPO issues over time. In particular, the DIPO volume of high-yield issues synchronizes with the business cycle and is greatly influenced by the receptiveness of investors to risky issues. In comparison, investment-grade issues display a steady or countercyclical pattern across various phases of the business cycle.

Our study is also the first to examine the dynamics between DIPO waves and EIPO waves. We show that EIPOs lead DIPOs. This causal relation is driven by the interaction between EIPOs and speculative-grade DIPO issues, suggesting that issuers' decisions on high-yield DIPOs and EIPOs are driven by common macroeconomic factors.

\footnotetext{
${ }^{7}$ The Granger causality test results are available from the authors.
} 


\section{References}

Andrews, D., and W. Ploberger, 1994, Optimal tests when a nuisance parameter is present only under the alternative, Econometrica 62, 1383-1414.

Baker, M., 2009, Capital market driven corporate finance, Annual Review of Financial Economics 1, 181-205.

Baker, M., and J. Wurgler, 2002, Market timing and capital structure, Journal of Finance 57, 1-32.

Blume, M. E., D. B. Keim, and S. A. Patel, 1991, Returns and the volatility of low grade bonds, Journal of Finance $46,49-74$.

Butler, A., G. Grullon, and J. Weston, 2006, Can managers successfully time the maturity structure of their debt issues? Journal of Finance 61, 1731-58.

Caballero, R., and A. Krishnamurthy, 2008, Collective risk management in a flight to quality episode, Journal of Finance 63, 2085-2121.

Cai, K., J. Helwege, and A. Warga, 2007, Underpricing in the corporate bond market, Review of Financial Studies 20, 2021-46.

Choe, H., R. Masulis, and V. Nanda, 1993, Common stock offerings across the business cycle: Theory and evidence, Journal of Empirical Finance 1, 3-31.

Datta, S., M. Iskandar-Datta, and A. Patel, 1997, The pricing of initial public offers of corporate straight debt, Journal of Finance 52, 379-96.

Datta, S., M. Iskandar-Datta, and A. Patel, 2000, Some evidence on the uniqueness of initial public debt offerings, Journal of Finance 55, 715-43.

Dittmar, A., and A. Thakor, 2007, Why do firms issue equity? Journal of Finance 62, 1-54.

Erel, I., B. Julio, W. Kim, and M. Weisbach, 2012, Macroeconomic conditions and capital raising, Review of Financial Studies 25, 341-76.

Fama, E. F., and K. R. French, 1989, Business conditions and expected returns on stocks and bonds, Journal of Financial Economics 25, 23-49.

Fama, E. F., and K. R. French, 1992, The cross-section of expected stock returns, Journal of Finance 47, 427-65.

Fama, E. F., and K. R. French, 1993, Common risk factors in the returns on stocks and bonds, Journal of Financial Economics 33, 3-56.

Gao, Y., C. Connie, and R. Zhong, 2006, Divergence of opinion and long-term performance of initial public offerings, Journal of Financial Research 29, 113-29.

Hale, G., and J. Santos, 2008, The decision to first enter the public bond market: The role of firm reputation, funding choices, and bank relationships, Journal of Banking and Finance 32, 1928-40.

Jung, K., Y.-C. Kim, and R. Stulz, 1996, Timing, investment opportunities, managerial discretion, and security issue decisions, Journal of Financial Economics 75, 159-85.

Korajczyk, R., and A. Levy, 2003, Capital structure choice: Macroeconomic conditions and financial constraints, Journal of Financial Economics 68, 75-109.

Lamont, O., and J. Stein, 2006, Investor sentiment and corporate finance: Micro and macro, American Economics Review 96, 147-51.

Liew, J., and M. Vassalou, 2000, Can book-to-market, size and momentum be risk factors that predict economic growth? Journal of Financial Economics 57, 221-45.

Loughran, T., and J. R. Ritter, 1995, The new issues puzzle, Journal of Finance 50, 23-51.

Loughran, T., J. R. Ritter, and K. Rydqvist, 1994, Initial public offerings: International insights, Pacific-Basin Finance Journal 2, 165-200.

Lowry, M., 2003, Why does IPO volume fluctuate so much? Journal of Financial Economics 67, 3-40.

McLean, R., and M. Zhao, 2011, The business cycle, investor sentiment, and costly external finance, Working Paper, University of Albert.

Merton, R., 1987, A simple model of capital market equilibrium with incomplete information, Journal of Finance 42, 483-510.

Miller, M., 1977, Risk, uncertainty and divergence of opinion, Journal of Finance 32, 1151-68.

Mizen, P., J. Tsoukalas, and S. Tsoukas, 2009, How does reputation influence a firm's decision to issue corporate bonds? Working Paper, University of Nottingham.

Myers, S., and N. Majluf, 1984, Corporate financing and investment decisions when firms have information that investors do not have, Journal of Financial Economics 13, 187-221.

Nayak, S., 2010, Investor sentiment and corporate bond yield spreads, Review of Behavioral Finance 2, 59-80.

Pastor, L., and P. Veronesi, 2005, Rational IPO waves, Journal of Finance 60, 1713-54.

Polk, C., S. Thompson, and T. Vuolteenaho, 2006, Cross-sectional forecasts of the equity premium, Journal of Financial Economics 81, 101-41. 
Rajan, R. G., 1992, Insiders and outsiders: The choice between informed and arm's-length debt, Journal of Finance 47, 1367-1400.

Shalen, C. T., 1993, Volume, volatility, and the dispersion of beliefs, Review of Financial Studies 6, 405-34.

Shane, H., 1993, Comovements of low-grade debt and equity returns of highly leveraged firms, Journal of Fixed Income 4, 79-89.

Shen, J., and J. Yu, 2012, Investor sentiment and economic forces, Working Paper, University of Minnesota. Vuolteenaho, T., 2002, What drives firm-level stock returns? Journal of Finance 57, 233-64. 
